FACTA UNIVERSITATIS

Series: Visual Arts and Music Vol. 6, N $\mathrm{N}^{\circ} 1,2020$, pp. 73 - 81

https://doi.org/10.22190/FUVAM2001073Z

Review article

\title{
NURTURING CHOIR SINGING AMONG PRESCHOOL CHILDREN
}

UDC 78.087.681:[784.9+37.036-053.4]

\author{
Vesna Zdravković ${ }^{\text {, Ivana Đorđević }}{ }^{2}$ \\ ${ }^{1}$ Pedagogical Faculty in Vranje, University of Niš, Republic of Serbia \\ ${ }^{2}$ Public Preschool Pčelica Niš, Republic of Serbia
}

\begin{abstract}
We tried to use a variety of learning methods, forms and materials to successfully organize and implement music activities, and to identify the specifics and possibilities for the preschool children to sing in a choir. We tried to come up with the following findings: what should be done to properly form and set up a children's choir; what learning methods should be used with the choir in order to motivate children; which breathing exercises should be used for such young choir singers; which technical exercises should be used with children singing in the choir (melodic exercises and voice impostation), which are the proper learning topics and methods to develop a sense of rhythm; which is the right methodological approach to use when teaching music to preschool children. We believe that by organizing and completing these tasks with properly planned actions, we would be able to encourage, monitor and develop a wide range of different music skills of preschool children.
\end{abstract}

Key words: music skills, preschool age, children's choir, children's songs

\section{INTRODUCTION}

Singing is the foundation of the development of the basic music skills, especially in the early period of learning about music which creates the basis for 'creating' art lovers and admirers. The interaction between melody and word is the backbone of music language and has always been an integral expression and spontaneous need of people. Song have a crucial role in understanding and accepting the laws of music, and later in creating music dialogue. The unity of singing depends on melody and rhythm.

The variety of components that comprise the set of music skills is extensive, but also characterized by mutual intertwining and interdependence between these components, so the definition of music skills is always based on "the basic components - sense of rhythm,

Received June 22, 2020 / Accepted June 30, 2020

Corresponding author: Vesna Zdravković

University of Niš, Pedagogical Faculty in Vranje

E-mail: vesszdravkovic@gmail.com 
ability to distinguish pitch and memorizing musical compositions" (Stojanović 1996, 132). The set of music skills cannot be reduced only to those already mentioned, but it also includes more complex types such as - a neat sense of dynamic variation, sense of tone colour, sense of tonality, ability to memorize music, ability to reproduce music (sing and play), ability to adopt music theory, a sense for polyphonic (two-part) music, a sense of group singing and playing, the ability to comprehend harmony, the ability to understand aesthetics, and creative music skills.

"In order for a child to learn to speak, he or she must first listen to the adults talking, however, only after communicating with others do they acquire speaking skills. It is in the same way that they develop their music potential. If a child does not actively engage in singing, the most important music activity, if they do not imitate and explore sound patterns in music communication with adults, it would be the same as listening to the mother tongue without the possibility to interact with anyone." (Vučkovski and Stojadinović 2013, 358)

If we look at music from the children's point of view and listen to their statements in which they say that music brings them happiness and fun, that it allows them to play and be imaginative, that it brings them joy - because of singing, dancing and drawing and that it provides them with what they need, we will then understand the role and importance of music in children's lives. By creating an atmosphere for an enjoyable music experience, and by choosing simple musical forms adapted to children's vocal abilities, their ability to listen, play and actively develop coordination between their moves and music, we will thenbe able to organize and implement music activities. By using all forms of musical expression and with an approach unique to each child, we oppose musical kitsch, and encourage and support children's musical creativity.

"By singing in a choir, the children learn to collaborate; they practise friendly solidarity and experience power that comes from working together as a whole. Each child becomes a responsible part of a group that must function as a team in order to create a wonderful united sound. When children master the complex task of singing in a choir, their selfconfidence grows. Such a successful performance gives the child an inner sense of achievement and satisfaction. By expressing themselves through music, they experience themselves as unique and talented beings. Singing in a choir gives a child the opportunity to discover his or her uniqueness, based on which the self-confidence and understanding of one's own value is built." (Habermeyer 2001, 114)

By singing in a choir, the children improve their singing skills, their music knowledge and learn new children's musical compositions with which they expand their music experience. In the choir, each child learns what the collective responsibility means, what conscious discipline and devotion to the idea of playing music together mean. Working with a preschool choir is a long, complex and very demanding process. Organizing choir rehearsals, the methodology used to work with the choir, excellent knowledge of pedagogy, as well as the age of the choir singers and the choir arrangement are the main prerequisites for a good-quality choir. Our extensive experience in working with the preschool choir led us to the truth about the importance and value of choral singing of preschool children and we can state the following: the choir sings in harmony thanks to the consistent adherence to the previously agreed rules - listen to yourself and to the friend standing next to you, children correct each other's singing mistakes; the choirmaster's instructions should be listened to; develop conscious discipline while singing. Well-designed and age-appropriate teaching and learning methods contribute to singing in harmony by working on children's sense of rhythm, through breathing exercises and techniques, and synchronized singing during articulation and diction exercises, as well as the group singing of children's songs. 
These teaching methods allow us to we prepare children for future musical development in the early school period - "Most teachers believe that student engagement in the school choir and orchestra is the best form of encouragement (54.2\%), which is understandable given the cost-effectiveness of organizing these activities in schools, where relevant factors of musical talentcan develop through group work" (Nikolić 1/2017, 329).

\section{ANALYSIS DESCRIPTION AND RESUlTS}

The preschool Choir Zlatne pčelice of the Pčelica preschool from Niš is used as the sample preschool institution. The choir was arranged with a careful selection of children who otherwise attend various kindergartens in the city of Niš. Except for the choir rehearsals, the choirmaster does not take part in the regular education process of these children. Given the importance of this choir for the preschool institution (the Choir performs throughout Serbia at festivals and competitions, as well as at the city festivals and concerts), we were interested in whether each new generation of choir singers showed good enough results thanks to the same teaching methods applied by the teacher-choirmaster. A total of 189 children participated in the study, 160 of which were girls and 29 were boys. These children are the sixth generation/group of the Preschool Institution Pčelica Choir in Niš, between April 2004 and April 2009. All these groups were included children who attended preschool and were of mixed age - from the age of four to the age of seven. The children who were included in this study have a normal mental and physical status and have healthy organs of speech and hearing.

By analysing the singing of each generation/group of the preschool choir, we concluded that there was a complete dissonance (disharmony) of children's voices during group singing. The cause might be the fact that all these children were introduced with choral singing for the first time at that age and did not have any similar experiences.

Certain steps are required to achieve the desired harmony in choral singing. At the very beginning of working with a choir, the completion of general and specific tasks is implied.

General tasks:

- Encourage and support children to socialize with each other;

- Develop positive emotions towards the choirmaster and choir;

- Develop and nurture love and devotion to the idea of singing together;

- Introduce children to the rules of group singing;

- Introduce children to the recommendations on how to keep the vocal apparatus healthy;

- Introduce new elements of behaviour during public performances;

- Develop a sense of collective responsibility;

- Respect children's attitudes and opinions about choral activities.

Specific tasks:

- Design and apply appropriate methods by which we achieve the harmony of children's voices during choral singing;

- Advise the children to listen to themselves and the friend standing next to them and to correct each other's singing mistakes;

- Advise the children that the choirmaster's instructions should be listened to during choral singing;

- Develop a conscious discipline during choral singing with a consistent and fair attitude of the choirmaster. 
In addition to monitoring and respecting the natural musical development of children, their interests and musical-rhythmic abilities, we carefully plan and apply work methods to all segments of choral activities, in order to harmonize children's voices during choral singing.

Voice harmonization in a preschool choir implies the following activities:

1. Developing a sense of rhythm (two-beat, three-beat and four-beat rhythm pattern) with counting nursery rhymes, aligned and harmonized with speech rhythm, in all possible forms - using fingers, palms, combination of palm and back of the palm, clapping the knees or stomping on the floor, and with various music games performed during frontal instruction, in groups or in pairs;

2. Breathing exercises where all children do all exercises at the same time;

3. Synchronized singing during articulation and diction exercises during choral singing exercises (unison and simultaneous singing of intervals and shorter vocalises ac companied by a musical instrument).

4. Practising group singing (children and choirmaster singing together).

5. Harmony, without individual vocal "jumps" by listening to and imitating the choirmaster's singing, by listening to the music instrument that accompanies the group singing and "tells you" how to sing.

The analysis of the final state of all practical activities of the preschool choir led us to the conclusion that the choir can harmonize their singing only through the adoption and compliance with all of the previously mentioned tasks and through a collective, dedicated and consistent effort and focus on all planned activities.

Successful results have been achieved thanks to the:

- Methodology used by the choirmaster when doing the breathing exercises with the choir;

- Melodic exercises and voice impostation;

- Proper learning topics and methods to develop a sense of rhythm;

- Right songs and methodological approach to used when singing.

These items represent a clear path and the main precondition to achieve the desired level of success of the choir, and confirm our initial assumption.

We will describe our study activities in detail and present the analysis of methodological procedures used while doing the breathing exercises with children - choir singers. Since these breathing exercises are always done before the actual singing, the choir rehearsals (we have around 65-70 rehearsals a year) become monotonous and less interesting to children over time. This can be a problem for us and it can diminish children's future interest in choral singing. That is why we have designed special breathing exercises and adapted them to preschool children. As a teaching and learning method, children's play is the basis of every breathing exercise. We deliberately introduced humorous elements into these exercises and thus made them one of the children's favourite choral activities. We perform all of these exercises together with the children all the time - we show them how to do the breathing exercises correctly. 
We divided the breathing exercises into three groups.

- Group one:

1. Exercise name - Iks-men [X-Men]

Children are standing and holding their hands in the X position (arms crossed in front of them). They inhale through the nose while raising their arms above their heads. While lowering the hands to the initial (x) position, the children exhale through the nose.

2. Exercise name - Smešna vežba [Funny exercise]

Children are standing. Palms should be on the hips, and the body leaning forward. Children should inhale with a swift body movement to the back, and exhale by gently returning to the starting position.

3. Exercise name-Prskalice [Water guns]

Children are standing and inhaling through the nose with swiftly spreading their arms. By joining their outstretched arms in front of the body, they make water guns with their palms. They "spray" each other with constant pronunciation of the sound prs, prs, prs [shhh, shhh, shhh...]. When they empty the "water guns", they "fill them up" with air by swiftly spreading their arms, and inhaling the air through the nose. The game is over when they "spray" their choirmaster with the "water guns".

4. Exercise name - Opasna vežba [Difficult exercise]

Children are standing up. We inhale and hold our breath. We count to five. We breathe out. We play the game carefully 2 to 3 times. We remind the children to do this exercise only with the choirmaster in the kindergarten.

5. Exercise name-Opasne zmije [Dangerous snakes]

Children are standing up. The palm of one hand is placed on the diaphragm. We hiss intermittently like snakes s, s, s...and follow the position of the diaphragm.

6. Exercise name-Baloni [Balloons]

Children are standing up. Children imitate inflating birthday balloons. After we "inflate" them, we let them fly away.

7. Exercise name-Perce [Feather]

Children are standing up. We tell children to imagine having a feather in their pocket. We ask them to take it out of their pocket. We raise the feather above our heads and blow into it all the time - so that it does not fall to the floor. We play this game for as long as the children enjoy it.

8. Exercise name-Lift [Elevator]

Children are standing up. Arms are on the waist. By saying "click" (we send the elevator up) the arms are lifted to the ribs while pronouncing bzzz... We exhale and feel with the fingers the rib cage returning back in. We inhale, expanding the rib cage (we feel the position of the rib cage with our fingers all the time) and slowly and quietly release the air to a certain sound. For example, like balloons - sssss ..., like a pressure cooker in the mother's kitchen - shhhh ..., like the wind - fijuuuu, fijuuu.. [whoosh, whoosh ... ], like bees - zzzzz... [buzz, buzz...]. With each new sound, we repeat the exercise from the beginning.

- Group two:

Breathing exercises combined with a light walk, with a gentle singing of songs familiar to children.

- Group three:

Breathing exercises with stories. An example of one of the stories: 


\section{One ordinary morning}

It is early morning. We are still in bed. We are sleeping (we take a deep breath through the nose, mouth closed). The alarm goes off (we imitate the alarm clock sound zzzzz). We stretch and yawn (aaaaa). Mom has already made some tea. We take the cup, bring it to our lips but - the tea is hot! We take the teaspoon and bring it to our lips. We blow into the teaspoon full of tea (ffff). Now the tea in the cup has cooled down. We take the cup and sip our tea (we inhale through our mouths imitating sipping-swiftly breathing in). As we get dressed, a big fly flies over our heads (quietly - zzzz). We approach the mother's rose on the table and smell it (we inhale through the nose). The rose smells so nicely! (children repeat this sentence while exhaling). Look, a bee is flying over mother's flowers (medium loud - zzzzz). We get dressed quickly and get in the car. Mom drives us to kindergarten (children imitate the sound of a car - vroom, vroom). Stop! Train crossing. The train is coming (we imitate the sound of the train passing, with dynamic nuances).We have arrived at the kindergarten. Kindergarten is full of birthday balloons! We take them and inflate them (we imitate inflating balloons). We throw them above our heads and blow (children "blow" into the balloons with short exhalations, with their heads raised). The party has begun!

This type of practical work with the choir has shown that these breathing exercises, properly implemented and combined, bring positive changes to the choir performance. The children are joyful and motivated to keep on singing.

We will begin the analysis of the melodic exercises and voice impostation by reviewing the exercises used. We tried to design these exercises to be interesting and fun, and appropriate for the age of these children.

We firstly sang the same tone played on the piano. We changed the syllables to match the desired tone (e.g. ne, ni, ne, na, non or ma, me, mi, mo, mum, etc.), and asked the children to follow their singing with their hands under their chins. This is how children feel their "resonance box". While singing, we compared the flat tone with "a river that flows slowly and evenly'. We dynamically nuanced all the intervals sung, from decrescendo to crescendo.

After that, the following types of exercises were done:

- Exercises including three tones: ascending (e.g. Re, Mi, Fa), using the comparison "like a cat climbing three steps", and descending "like a cat going down three steps";

- Exercises including the ascending and descending thirds, using the comparison "like a bunny jumping over the bush";

- Exercises including the ascending thirds and descending seconds, using the comparison "as if we are climbing to the top of the building and going down the stairs";

- Exercises including the descending thirds, using the comparison "like a frog jumping from a water lily to a water lily, and then into the water - splash".

While doing these exercises, we occasionally ask the children to put the hand on their belly. This is how we feel the vibration of the body while singing.

During the melodic and voice impostation exercises, we noticed that children make a significant effort to meet the demands of the choirmaster. That is why we were careful regarding the frequency of these exercise and often used the songs that the children already knew. 
We will present the analysis of proper learning topics and methods to develop a sense of rhythm by talking about counting rhymes. By listening to the opinions of music pedagogues and the opinions of the children from our choir, we chose a series of counting rhymes that are appropriated to the age of the children, both textually and rhythmically. Those were the counting rhymes about animals, family, nature, children's play, or certain counting rhymes that do not make sense text-wise, but give children the opportunity to have fun, and are at the same time educational games even though the words used are meaningless or are simply syllables (e.g. Elem, belem, barba delen, zita, gita, okma, lokma, or Zlatna smokva, zlatna jabuka, idi s njom - napolje! [Golden fig, golden apple, go with her-outside!]). By following the musical requirements, we chose the counting rhymes based on the goal we wanted to achieve, so we, accordingly, learned the counting rhymes that allow children to learn about the two-beat, three-beat and four-beat rhythm pattern. These rhymes were presented to the children through play. We played with them using our bodies as the instrument or using Orff instruments. We occasionally introduced certain rhythmic images to make learning about these rhymes more interesting. These exercises were done individually or in pairs - practising them with friends from the choir.

When choosing the songs for choral singing, we made sure that:

- Song range is appropriate for the age of the choir singers;

- There are no major interval jumps;

- They are interesting to the children;

- They carry an educational and positive message;

- They develop children's vocal apparatus;

- They nurture positive feelings (joy, happiness, love...);

- They are moderate tempo songs;

- They are appropriate as for music and rhythm (within the limits of children's abilities and understandings).

The methodological approach included the following steps:

- Present the children's song in its entirety with a musical instrument;

- Explain the unknown words from the lyrics;

- Learning individual song stanzas along with the choirmaster singing, with and without a musical instrument;

- Connect the stanzas and practice them;

- Singing the whole song (whole choir or pairs, per the choir members' wish);

- Expressive song tuning.

After analysing the harmonization of children's voices when singing children's compositions in the preschool choir, by using the well-designed and age-appropriate teaching and learning methods to work on children's sense of rhythm, with breathing exercises and techniques, and synchronized singing during articulation and diction exercises, we can conclude that the choir manages to sing in harmony due to the consistent adherence to the agreed rules: listen to yourself and to the friend standing next to you, correct each other's singing mistakes; listen to the choirmaster's instructions; develop conscious discipline while singing. 


\section{CONCLUSION}

"The studies focusing on aesthetic education and/or aesthetic experience indicate that the pedagogues are primarily interested in preschool and primary school age, which is understandable, given that there is a common view that aesthetic education should be an integral part of an individual's life starting from the early childhood, and that its role is very important during the primary school period" (Zdravić-Mihailović, 2014: 646). It is certain that little attention is paid to such a complex activity as choral singing by preschool children. We believe that children of this age can meet all the requirements the choirmaster puts before them, and that, just like true professionals, they can sing a complex children's choir program.

It is natural to pass the things we believe in and love to those we love. That is why we have decided to allow the children who are there, in front of us, to meet their personal, developmental and musical needs and to create for them a unique place where they can socialize and gain new singing experiences - the choir. Our commitment implies investing a lot of energy and time in this complex and long-lasting process, and it additionally implies continuous activities by the preschool choirmaster.

Working with choir singers of preschool age is specific and extremely demanding. In order for a teacher to successfully lead a preschool children's choir and influence the development of children's music skills, one should have good musicality, know the technique and culture of singing, have good vocal abilities (choirmaster is a role model for children and they imitate him/her while singing), this person should have formal music education - which means knowing to play one harmonic instrument. All this is not enough if the teacher-choirmaster is not familiar with the course of musical development at the preschool age and, if, in addition to professional knowledge, that person has no patience, love for children and personal enthusiasm for music.

After reviewing the results from this paper, it is necessary to emphasize the possible continuation of this research. A possible future research would be based on the topic of how many children were motivated and encouraged by singing in the Zlatna Pčelica Choir to continue their music education by joining a music school. If such children exist, and we are sure that they do, what would be the results of their further education and how much did the knowledge and music experience acquired in the preschool period contribute to their success?

In order to verify and understand the truth about the importance and value of choral singing of preschool children, we hope that in time the children's choirs in preschools will become a regular practice and that we will all admire children's choirs and their inspiring singing.

\section{REFERENCES}

Vučkovski, J., Stojadinović, A., (2013), Ritam i govor - elementi muzike i jezika [Rhythm and Speech Elements of Music and Language], Godisnjak [Yearbook], Book IV, Učiteljski fakultet, Vranje, pp. 357-362.

Zdravić-Mihailović, D., (2014), Pedagoški pristup tumačenju estetskog doživljaja muzike [Pedagogical Approach to the Interpretation of the Aesthetic Experience of Music], In: Tradicija kao inspiracija, Vlado S. Milosevic - etnomuzikolog, kompozitor i pedagog [Tradition as Inspiration, Vlado S. Milosevic - Ethnomusicologist, Composer and Pedagogue], Akademija umjetnosti, Banja Luka, pp. 642-651. 
Nikolić, I., (1/2017), Formalno muzičko obrazovanje nastavnika razredne nastave kao faktor identifikacije i podsticanja muzički talentovanih učenika [Formal Music Education of Class Teachers as a Factor in Identifying and Encouraging Musically Talented Students], Godisnjak [Yearbook], Book VIII, Pedagoški fakultet, Vranje, pp. 319-332.

Stojanović, G., (1996), Nastava muzičke kulture od I do IV razreda osnovne škole [Music Education from the 1st to the 4th Grade of Primary School], Zavod za udžbenike i nastavna sredstva, Beograd.

Habermeyer, S., (2001), Prava muzika za vaše dete [Good Music Brighter Children], INTER GRADEX TRADE, Čačak.

\section{NEGOVANJE HORSKOG MUZICIRANJA DECE PREDŠKOLSKOG UZRASTA}

Aktivnim delovanjem, uz bogatstvo i raznovrsnost metoda, oblika i sredstava za uspešno izvođenje muzičkih aktivnosti želeli smo da utvrdimo specifičnosti i mogućnosti pevanja dece predškolskog uzrasta $u$ horskom ansamblu. Pokušali smo da dođemo do sledećih saznanja: koje korake preduzeti da bi se formirao i pravilno postavio dečji hor; koje metode rada, u cilju motivacije dece, koristiti sa horom; koje vežbe disanja upotrebiti za male horske pevače; koje tehničke vežbe koristiti sa decom u horu (melodijske vežbe za upevavanje i postavku glasa), koji je pravilan izbor sadržaja i metoda za rad na razvoju osećaja za ritam; koji je pravilan izbor i metodički pristup, prilikom obrade pesama za predškolski uzrast. Pretpostavljamo da ćemo organizacijom i realizacijom ovih zadataka, planskim $i$ osmišljenim delovanjem, biti u mogućnosti da podstaknemo, pratimo i razvijamo celu lepezu različitih muzičkih sposobnosti dece predškolskog uzrasta.

Ključne reči: muzičke sposobnosti, predškolski uzrast, dečji hor, dečja pesma 